\title{
Optimization of Conditions and Production of Carboxy Methyl Cellulase by Bacteria Isolated from Higher Termite Soil
}

\section{Sreeremya $\mathbf{S}^{1 *}$, Nishaa $\mathbf{S}^{1}$ and Rajiv $\mathbf{P}^{2}$}

${ }^{1}$ Department of Biotechnology, Mercy College, Palakkad, Kerala, India

${ }^{2}$ Depatrment of Biotechnology, Karpagam Academy of Higher Education, Tamil Nadu, India

\begin{abstract}
The current work deals with the studies of isolation and preliminary characterization of the bacteria isolated from higher termite soil. Termites play an important role in the turnover and mineralization of complex biopolymers, such as wood and other cellulose and hemicelluloses containing materials. Lignocellulose is the most predominant component of the woody and dead plant materials, as well as it is the most abundant biomass on earth, especially in terrestrial ecosystems. Thus the work focuses on using lingo cellulosic waste efficiently for production of Carboxy Methyl Cellulase (CMC). As CMCase have higher hydrolyzing capacity than the other two cellulases, cellobiase and cellobiohydralases it has wide application in industry such as bread and baking industry, laundry etc. Thus the work focuses on identification of efficient bacterial species in this work 6 bacterial species were isolated among which 14 produced higher CMCase enzyme. After the morphological, biochemical and identification test, the 14 isolate was found to be Bacillus sp.
\end{abstract}

Keywords: Carboxy methyl cellulase (CMC); Cellulase

\section{Introduction}

Termites are a ubiquitous feature of tropical and subtropical soils, where their number exceeds $6000 \mathrm{~m}^{-2}$ and their biomass densities $(>50$ $\left.\mathrm{gm}^{-2}\right)$ often surpass those of grazing mammalian herbivores (0.0-7.5 $\mathrm{gm}^{-2}$ ). Both higher and lower termites have microbes and enzymes in their hindgut, and this is therefore where the most symbiosis occurs. Soil on the other hand is a highly heterogeneous environment [1] that contains a high diversity of microorganisms [2].

These microorganisms influence above ground ecosystems by contributing to soil structure and fertility among other roles [3]. Soil microorganisms are a valuable source of natural products providing important antibiotics for pharmaceuticals, enzymes and bioactive compounds for industries [4]. Since soil being a good habitat for the growth of many number of microorganisms, majorly observed microorganisms are bacteria: Bacillus sp, Klebsiella sp, Pseudomonas $\mathrm{sp}$, Serratia sp, Xanthomonas sp etc. Many fungal species are also obtained from higher termite soil, which include Aspergillus sp, Phoma sp, Neurospora sp, Trichoderma sp, Penicillium sp. The major actinomycetes species observed are Streptomyces sp, Geosmin sp, Nocardia sp. Cellulase consists of three different types of enzymes named as endoglucanases, exoglucanses and cellobiases. Several novel enzymes capable of degrading cellulose into sugars have insights from this discovery to create a high performance enzyme cocktail for processing plant biomass into biofuel.

Two cellulases, endoglucanase (CMCase), exoglucanases or $\beta-1,4$ glucan hydrolases enzymes were first reported to exist in termitomyces conidiophores of the "fungus garden" Bacterial cellulases have proved to be a better candidate than other microbial cellulases, with their secreted free cellulose complexes comprising all three components of cellulose. Plant cell walls are the most abundant renewable sources of fermentable sugars on the earth [5] and are the major reservoir of fixed carbon in nature. The major components of plant cell walls are cellulose, hemicellulose and lignin, with cellulose being the most abundant component. But plant woods commercially used for the production of paper. So an alternative substrate is required for production of cellulase enzyme. Rice straw, wheat straw, rice bran, wheat bran, when used as substrate there are some bacterial species mainly considered pathogen and degrades these substrates easily.
Several studies were carried out to produce cellulolytic enzymes from bio waste degradation process by many microorganisms including fungi such as Trichoderma, Penicillium, Aspergillus spp. etc. by Mandels $\mathrm{M}$ et al., Hoffman RM et al., Brown JA et al., Lakshmi Kant et al. [6-9] etc. Similarly cellulolytic property of bacterial species like Pseudomonas, Cellulomonas, Bacillus, Micrococcus and Cellovibrio sp were also reported. The specific cellulolytic activity shown by the bacterial species is found to be depending on the source of occurrence [10]. Some features of natural cellulosic materials are known to inhabit their degradation or bioconversion $[11,12]$. These are degree of crystallinity, lignification and the capillary structure of cellulose to cellulolytic enzymes and other hydrolytic agents. However, many physical, chemical and microbial pre-treatment methods for enhancing bioconversion of cellulosic materials have been reported $[12,13]$. Since the production of cellulase enzyme is a major process and economically viable, much work has been done on the production of cellulase from lignocellulosics and major attention has been given to use bagasse as substrate [12,13]. The bioconversion of various complex cellulosic waste materials such as bagasse [13], corncob [14]; saw dust [12] have been reported (Figure 1).

\section{Materials and Methods}

\section{Sample collection}

The higher termite soil sample was collected from three different regions of Palakkad district (Nelliyampati, Kallepully, Chittur). The samples were collected, serially diluted and was spread plated.

\footnotetext{
*Corresponding author: Sreeremya S, Department of Biotechnology, Mercy College, Palakkad, Kerala, India, Tel: 702-536-9665; E-mail: sreeremyasasi@gmail.com
}

Received January 29, 2016; Accepted February 18, 2016; Published February 23, 2016

Citation: Sreeremya S, Nishaa S, Rajiv P (2016) Optimization of Conditions and Production of Carboxy Methyl Cellulase by Bacteria Isolated from Higher Termite Soil. J Bioprocess Biotech 6: 270. doi:10.4172/2155-9821.1000270

Copyright: (C) 2016 Sreeremya S, et al. This is an open-access article distributed under the terms of the Creative Commons Attribution License, which permits unrestricted use, distribution, and reproduction in any medium, provided the original author and source are credited. 
Citation: Sreeremya S, Nishaa S, Rajiv P (2016) Optimization of Conditions and Production of Carboxy Methyl Cellulase by Bacteria Isolated from Higher Termite Soil. J Bioprocess Biotech 6: 270. doi:10.4172/2155-9821.1000270

Page 2 of 4

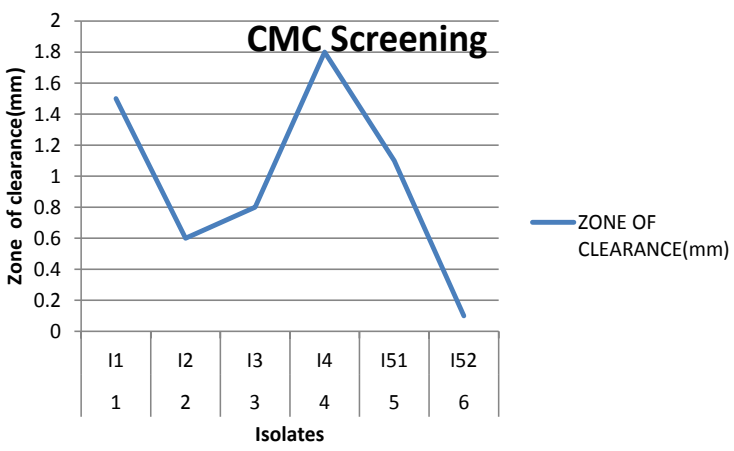

Figure 1: Preliminary CMC screening.

\section{Isolation of bacteria from higher termite soil}

The soil samples were isolated and were spread plated from the three soil samples. The six Colonies with visually distinguishable morphologies were selected and restreaked on Nutrient agar to obtain pure cultures isolates were labeled as I1, I2, I3, I4, I5 , I5 (Tables 1 and 2).

\section{Identification of bacteria}

Bacteria were identified and classified based on their physical and biochemical characteristics. Various biochemical test such as IMViC, TSI, Carbohydrate fermentation, Catalase, oxidase test, starch hydrolysis test were performed to identify the bacterial species (Tables 3-5).

\section{Screening}

The six isolates were inoculated by spot inoculation and incubated at $24-48 \mathrm{hrs} .1 \%$ of Congo red solution was added to the spot inoculated plates and then excess stains were removed by using $1 \mathrm{M} \mathrm{NaCl}$ and zone of clearance were observed as in Figure 1.

\section{Optimization of physiological condition}

Cellulases have versatile applications in textile, laundry, pulp and paper, fruit juice extraction, and animal feed additives [15]. In addition, they find use in saccharification of lignocellulosic agro residues to fermentable sugars which can be used for production of bioethanol, lactic acid, and single-cell protein [16]. Bacteria have been widely explored for cellulase production owing to their high growth rate, expression of multi enzyme complexes, stability at extreme temperature and $\mathrm{pH}$, lesser feedback inhibition, and ability to withstand variety of environmental stress [15]. Among them, Bacillus sp. continues to be dominant bacterial workhorse due to the capacity to produce and secrete large quantities of extracellular enzymes [17]. However, physical process parameters such as temperature, $\mathrm{pH}$, and agitation speed play a vital role for the cellulase production efficiency of the microorganisms. Agitation speed is an important factor which governs the dissolved oxygen level in the culture broth that affects cell growth of cellulase producing microorganism [18]

\section{Effect of temperature}

For estimation of optimum temperature, the enzyme activity was carried out at five different temperatures $\left(20^{\circ} \mathrm{C}, 30^{\circ} \mathrm{C}, 40^{\circ} \mathrm{C}, 50^{\circ} \mathrm{C}\right.$ and $60^{\circ} \mathrm{C}$ ) using $0.5 \mathrm{ml}$ of Carboxymethyl cellulose substrate.

\section{Effect of $\mathbf{p H}$}

The best $\mathrm{pH}$ for enzyme activity was determined by enzyme assay at different $\mathrm{pH}$ levels $(4,5,6,7,8)$. In order to find the effect of $\mathrm{pH}$ also $0.5 \mathrm{ml}$ of carboxymethyl cellulose is used as substrate.

\section{Results and Discussion}

The three samples were collected from higher termite soil. Serially diluted higher termite soil sample showed distinct colonies at $10^{-4}$ dilution. The selected colonies were labeled as I1, I2, I3, I4, I5 , I5 and was subjected to physical and biochemical characterization, the results were tabulated in Tables 1 and 2.

The Figure 1 shows the specific screening and CMCase assays. After the preliminary screening the I4 isolate was found to be more efficient for the CMCase activity. Optimization of physiological conditions ( $\mathrm{pH}$ and temperature) were analyzed as in Figures 2-5, thus I4 isolate at temperature $40^{\circ} \mathrm{C}$ at $\mathrm{pH} 6$ was more efficient as in Figures 6-9. In addition there were reports that the cellulase production by Aspergillus niger and bacterial strains such as Cellulomonas sp was observed over a wide range of temperatures between 30 to $50^{\circ} \mathrm{C}[19,20]$. In the current research since the I4 isolate utilized the Carboxy methyl cellulose during the screening test. The isolates was further analysed for the optimization: Temperature and $\mathrm{pH}$.

\begin{tabular}{|c|c|c|}
\hline Serial dilution & Colonies obtained (one quadrant) & $\begin{array}{c}\text { Colonies obtained } \\
\text { (four quadrant) }\end{array}$ \\
\hline $10-1$ & 525 & 2100 \\
\hline $10-2$ & 326 & 1304 \\
\hline $10-3$ & 245 & 980 \\
\hline $10-4$ & $\mathbf{2 0 0}$ & $\mathbf{8 0 0}$ \\
\hline $10-5$ & 163 & 652 \\
\hline $10-6$ & 113 & 452 \\
\hline $10-7$ & 98 & 392 \\
\hline
\end{tabular}

Table 1: Enumeration of bacterial colonies.

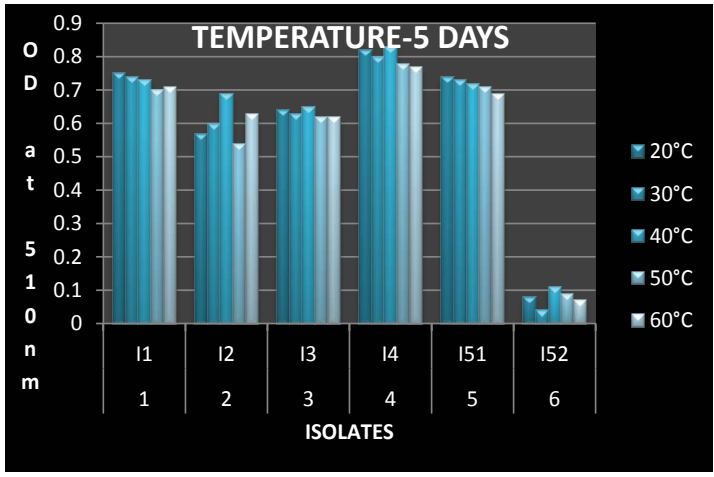

Figure 2: For estimation of optimum temperature, the enzyme activity was carried out at five different temperatures $\left(20^{\circ} \mathrm{C}, 30^{\circ} \mathrm{C}, 40^{\circ} \mathrm{C}, 50^{\circ} \mathrm{C}\right.$ and $60^{\circ} \mathrm{C}$ ) using $0.5 \mathrm{ml}$ of Carboxymethyl cellulose substrate for 5 days.

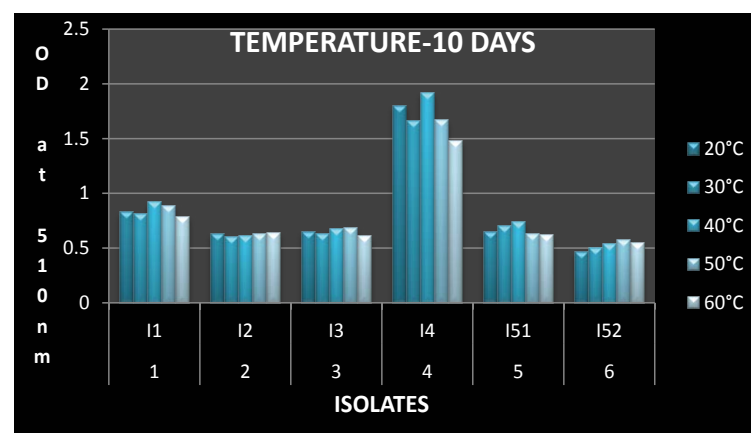

Figure 3: For estimation of optimum temperature, the enzyme activity was carried out at five different temperatures $\left(20^{\circ} \mathrm{C}, 30^{\circ} \mathrm{C}, 40^{\circ} \mathrm{C}, 50^{\circ} \mathrm{C}\right.$ and $60^{\circ} \mathrm{C}$ ) using $0.5 \mathrm{ml}$ of Carboxymethyl cellulose substrate for 10 days. 
Citation: Sreeremya S, Nishaa S, Rajiv P (2016) Optimization of Conditions and Production of Carboxy Methyl Cellulase by Bacteria Isolated from Higher Termite Soil. J Bioprocess Biotech 6: 270. doi:10.4172/2155-9821.1000270

Page 3 of 4

\begin{tabular}{|c|c|c|c|c|c|c|c|c|c|c|}
\hline S No & Name & Size & Shape & Colour & Margin & Surface & Elevation & Transparency & Viscosity \\
\hline 1. & 11 & Large & Undulate & Yellow & Undulate & Smooth & Flat \\
\hline 2. & 12 & Medium & Circular & Light yellow & Entire & Smooth & Flat in growing & Transparent \\
\hline 3. & 13 & Small & Circular & Light white & Entire & Smooth & Low convex & Translucent \\
\hline 4. & 14 & Large & Circular & Creamy & Entire & Smooth & Flat in growing & Opaque \\
\hline 5. & 15 & Small & Circular & White & Diffuse & Finely granular & Flat & Moist \\
\hline 6. & 15 & Small & Irregular & White & Diffuse & Glossy & Flat & Ropy \\
\hline
\end{tabular}

Table 2: Physical Characterization.

\begin{tabular}{|c|c|c|c|c|c|c|c|c|c|}
\hline S No & $\begin{array}{l}\text { Bacterial } \\
\text { isolates }\end{array}$ & Gram stain & Microscopic features & Indole test & Methyl red & VP test & Citrate utilization & Oxidase & Catalase \\
\hline 1. & Isolate 1 & -ve & Rod shaped & -ve & -ve & $+\mathrm{ve}$ & $+\mathrm{ve}$ & $+v e$ & $+v e$ \\
\hline 2. & Isolate 2 & -ve & Rod shaped & -ve & $+\mathrm{ve}$ & $+v e$ & $+v e$ & $+v e$ & + ve \\
\hline 3. & Isolate 3 & -ve & Rod shaped & -ve & $+v e$ & $+\mathrm{ve}$ & $+v e$ & $+v e$ & -ve \\
\hline 4. & Isolate 4 & $+v e$ & Rod shaped & -ve & $+v e$ & $+\mathrm{ve}$ & -ve & $+\mathrm{ve}$ & -ve \\
\hline 5. & Isolate $5_{1}$ & -ve & Rod shaped & -ve & $+v e$ & -ve & $+v e$ & $+v e$ & + ve \\
\hline 6. & Isolate $5_{2}$ & -ve & Rod shaped & -ve & $+v e$ & $+v e$ & $+\mathrm{ve}$ & $+\mathrm{ve}$ & $+\mathrm{ve}$ \\
\hline
\end{tabular}

Table 3: Microscopic Examination and Biochemical Characterization.

\begin{tabular}{|c|c|c|c|c|c|}
\hline S No & Isolates & Sucrose & Glucose & Mannitol & Inositol \\
\hline 1. & 11 & Ap/NG & Map/NG & Map/NG & Map/NG \\
\hline 2. & 12 & Ap/NG & Map/NG & Map/NG & Ap \\
\hline 3. & 13 & Ap/NG & Map/NG & Map/NG & Map/NG \\
\hline 4. & 14 & Ap/NG & Nc & Ap/NG & Map/NG \\
\hline 5. & 151 & Map/NG & Map/NG & Map/NG & Map/NG \\
\hline 6. & 152 & Ap/NG & Map/NG & Map/NG & Map/NG \\
\hline
\end{tabular}

Abbreviations: Ap/NG: Acid production/No gas; NG: No gas; Map: Minor acid production; Ap: Acid production; Nc: No change

Table 4: Carbohydrate Fermentation Test.

\begin{tabular}{|c|c|c|}
\hline S No & Isolate & TSI \\
\hline 1. & 11 & $\left(\mathrm{AK}_{\mathrm{S}} / \mathrm{A}_{\mathrm{B}}\right)$ \\
\hline 2. & 12 & $\left(\mathrm{AK}_{\mathrm{S}} / \mathrm{A}_{\mathrm{B}}\right)$ \\
\hline 3. & 13 & $\left(\mathrm{AK}_{\mathrm{S}} / \mathrm{A}_{\mathrm{B}}\right)$ \\
\hline 4. & 14 & $\mathrm{~A}_{\mathrm{s}} \mathrm{A}_{\mathrm{B}}$ \\
\hline 5. & 151 & $\mathrm{Nc}$ \\
\hline 6. & 152 & $\left(\mathrm{AK}_{\mathrm{S}} / \mathrm{A}_{\mathrm{B}}\right)$ \\
\hline
\end{tabular}

Abbreviations: $\mathrm{AK}_{\mathrm{S}} / \mathrm{A}_{\mathrm{B}}$ : Alkaline slant/acid butt; $\mathrm{N}_{\mathrm{c}}$ : No change; $\mathrm{A}_{\mathrm{s}} / \mathrm{A}_{\mathrm{B}}$ : Acid slant/ Acid butt

Table 5: Triple sugar iron test.

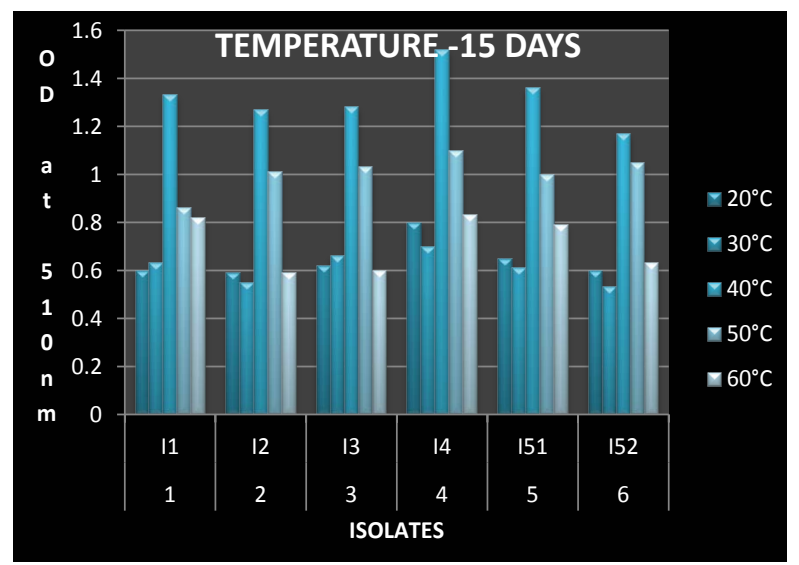

Figure 4: For estimation of optimum temperature, the enzyme activity was carried out at five different temperatures $\left(20^{\circ} \mathrm{C}, 30^{\circ} \mathrm{C}, 40^{\circ} \mathrm{C}, 50^{\circ} \mathrm{C}\right.$ and $60^{\circ} \mathrm{C}$ ) using $0.5 \mathrm{ml}$ of Carboxymethyl cellulose substrate for 15 days.

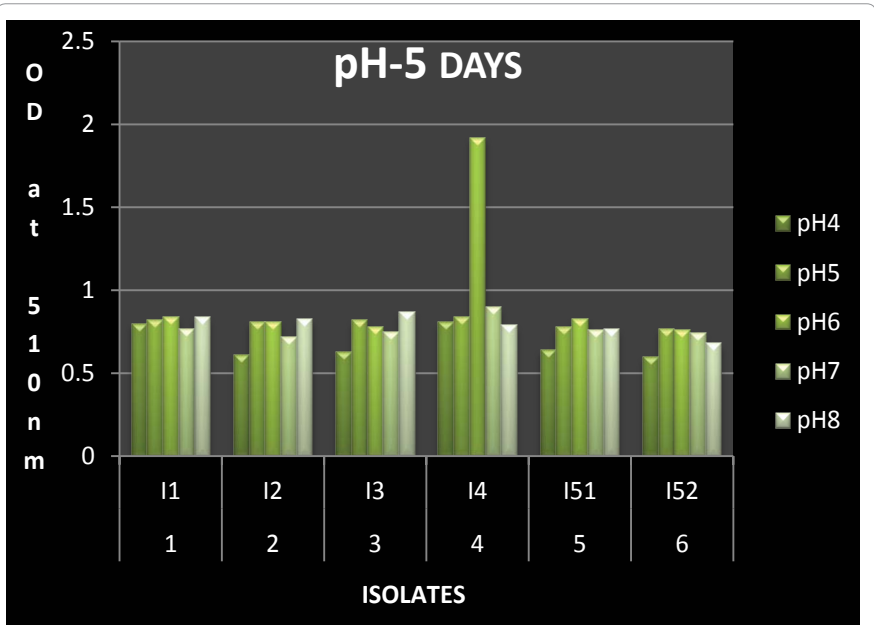

Figure 6: The best $\mathrm{pH}$ for enzyme activity was determined by enzyme assay at different $\mathrm{pH}$ levels $(4,5,6,7,8)$. In order to find the effect of $\mathrm{pH}$

also $0.5 \mathrm{ml}$ of carboxymethyl cellulose is used as substrate for 5 days.

Figure 5: For estimation of optimum temperature, the enzyme activity was carried out at five different temperatures $\left(20^{\circ} \mathrm{C}, 30^{\circ} \mathrm{C}, 40^{\circ} \mathrm{C}, 50^{\circ} \mathrm{C}\right.$ and $60^{\circ} \mathrm{C}$ ) using $0.5 \mathrm{ml}$ of Carboxymethyl cellulose substrate for 20 days.

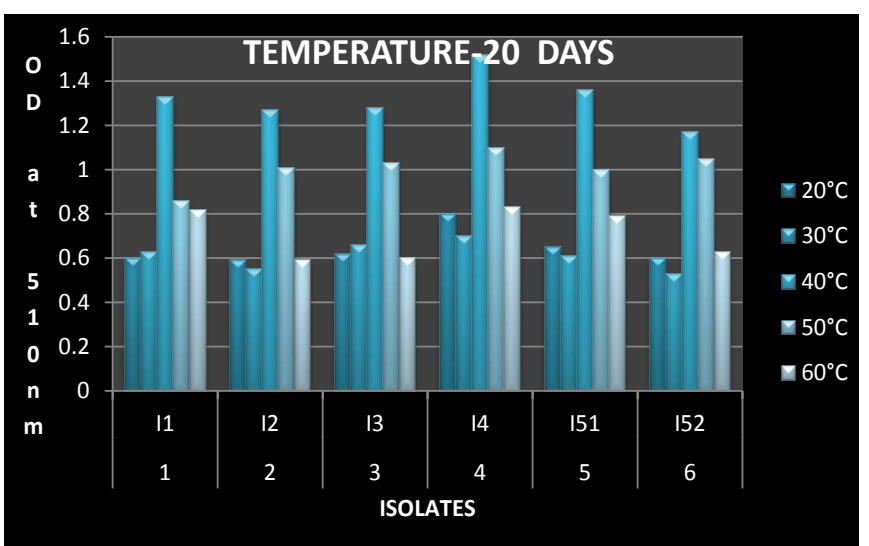


Citation: Sreeremya S, Nishaa S, Rajiv P (2016) Optimization of Conditions and Production of Carboxy Methyl Cellulase by Bacteria Isolated from Higher Termite Soil. J Bioprocess Biotech 6: 270. doi:10.4172/2155-9821.1000270

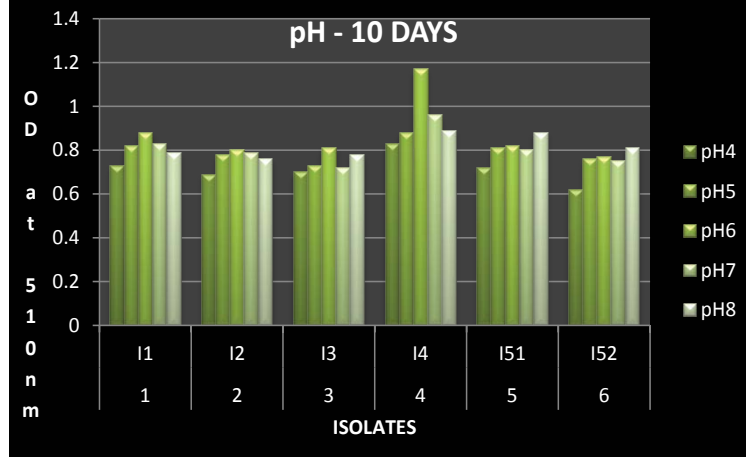

Figure 7: The best $\mathrm{pH}$ for enzyme activity was determined by enzyme assay at different $\mathrm{pH}$ levels $(4,5,6,7,8)$. In order to find the effect of $\mathrm{pH}$ also $0.5 \mathrm{ml}$ of carboxymethyl cellulose is used as substrate for 10 days.

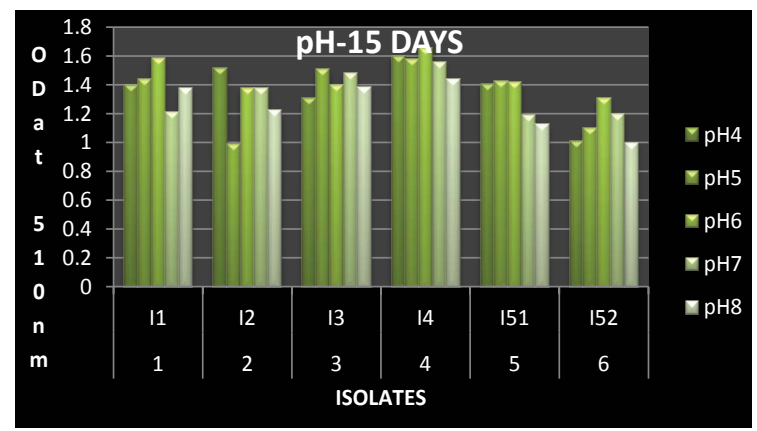

Figure 8: The best $\mathrm{pH}$ for enzyme activity was determined by enzyme assay at different $\mathrm{pH}$ levels $(4,5,6,7,8)$. In order to find the effect of $\mathrm{pH}$ also $0.5 \mathrm{ml}$ of carboxymethyl cellulose is used as substrate for 15 days.

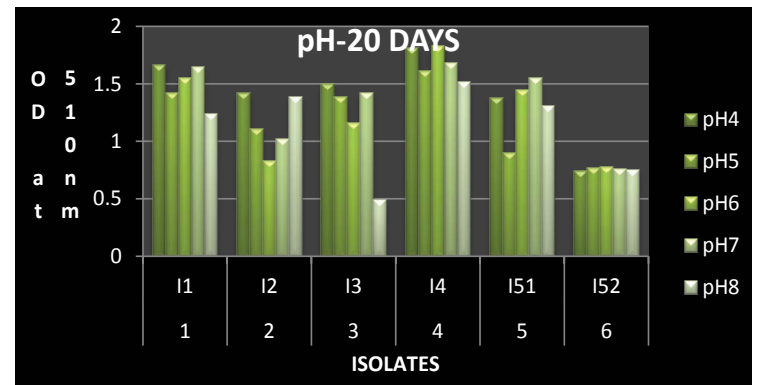

Figure 9: The best $\mathrm{pH}$ for enzyme activity was determined by enzyme assay at different $\mathrm{pH}$ levels $(4,5,6,7,8)$. In order to find the effect of $\mathrm{pH}$ also $0.5 \mathrm{ml}$ of carboxymethyl cellulose is used as substrate for 20 days.

\section{Conclusion}

The bacterial species were isolated from higher termite soil. The six isolates after pure culturing, biochemical characterizations were carried out. The efficiency of bacterial species to produce CMCase was analyzed by screening. In screening the I4 isolate produced more zone of clearance so the organism (I4) utilizes the substrate $1.6 \mathrm{~cm}$, when compared to other isolates. After the screening the optimizations of conditions ( $\mathrm{pH}$ and temperature) were recorded for 20 days with 5 days of intervals. The I4 isolates at fifteenth day at $\mathrm{pH} 6$ and temperature $40^{\circ} \mathrm{C}$ were observed to be more efficient and the I4 isolate was identified as Bacillus sp. Thus Bacillus sp has more potential to produce CMCase enzyme when compared to other isolates. Since CMCase has great applications in food and pharmaceutical industries. These findings suggest that Bacillus sp at specific $\mathrm{pH}$ and temperature were found to be more potential.

\section{References}

1. Daniel R (2004) The soil metagenome--a rich resource for the discovery of novel natural products. Curr Opin Biotechnol 15: 199-204.

2. Liesack W, Janssen PH, Rainey FA, Ward-Rainey NL, Stackebrandt E (1997) Microbial diversity in soil: The need for a combined approach using molecular and cultivation Techniques. In: Modern Soil Microbiology. Elsas JD, Trevors JT, Wellington EMH (Eds). Marcel Dekker, New York, USA, pp: 375-439.

3. O'Donnnell AG, Seasman M, Macne AN, Davies T (2001) Plants and fertilisers as drivers of change in microbial community structure and function in soils. Plant and Soil 232: 135-145.

4. Strohl WR (2000) The role of natural products in a modern drug discovery program. Drug Discov Today 5: 39-41.

5. Himmel ME, Ruth MF, Wyman CE (1999) Cellulase for commodity products from cellulosic biomass Curr Opin Biotechnol 10: 358-364.

6. Mandels M, Reese ET (1999) Fungal cellulases and the microbial decomposition of cellulosic fabric. J Ind Microbiol Biotechnol 22: 225-240.

7. Hoffman RM, Wood TM (1985) Isolation and partial characterization of a mutant of Penicillium funiculosum for the saccharification of straw. Biotechno Bioeng 27: 81-85.

8. Brown JA, Collin SA, Wood TM (1987) Development of a medium for high cellulase, xylanase and $\beta$-glucosidase production by a mutant strain (NTG III/6) of the cellulolytic fungus Penicillium pinophilum. Enzyme Microbial Technol 9 : 355-360.

9. Lakshmikant, Kamal, Mathur SN (1990) Cellulolytic activities of Chaetomium globosum on different cellulosic substrates. World J Microbiol Biotechnol 6: 23-26.

10. Saxena S, Bahadur J, Varma A (1993) Cellulose and hemicellulose degradation bacteria from termite gut and mound soils of India. Int J Microbiol 33: 55-60.

11. Solomon BO, Layokun SK, Nwesigwe PK, Olutiolo PO (1990) Hydrolysis of saw dust by cellulase enzyme derived from Aspergillus flavus Linn. Isolates NSPR 101 beyond the initial fast rate period. JNSCHE 9: 1-2.

12. Solomon BO, Amigun B, Betikue TV, Ojumu T, Layokun SK (1999) Optimization of cellulase production by Aspergillus flavus Linn. isolates NSPR 101 grown on bagasse. Journal of Nigerian Society of Chemical Engineers 16: 61-68.

13. Kanosh AL, Essant SA, Zeinat AM (1999) Biodegradation and utilization of bagasse with Trichoderma ressei. Polym Degrad Stab 62: 273-276.

14. Ojumu T, Solomon V, Bamidele O, Betiku E, Layokun SK, et al. (2003) Cellulase production by Aspergillus flavus Linn Isolate NSPR 101 fermented in sawdust bagasse and corncob. African J Biotechnol 2: 150-152.

15. Bhat MK (2000) Cellulases and related enzymes in biotechnology. Biotechnol Adv 18: 355-383

16. Sánchez OJ, Cardona CA (2008) Trends in biotechnological production of fue ethanol from different feedstocks. Bioresour Technol 99: 5270-5295.

17. Jo KI, Lee YJ, Kim BK, Lee BH, Chung CH, et al. (2008) Pilot-scale production of carboxymethylcellulase from rice hull by Bacillus amyloliquefaciens DL-3. Biotechnol Bioprocess Eng 13: 182-188.

18. Chipeta ZA, du Preez JC, Christopher L (2008) Effect of cultivation pH and agitation rate on growth and xylanase production by Aspergillus oryzae in spent sulphite liquor. J Ind Microbiol Biotechnol 35: 587-594.

19. Jaradat Z, Dawagreh A, Ababneh Q, Saadoun I (2008) Influence of culture conditions on cellulase production by Streptomyces sp. (Strain J2). Jordan J Biol Sci 1: 141-146.

20. Milala MA, Shugaba A, Gidado A, Ene AC, Wafar JA (2005) Studies on the use of agricultural wastes for cellulase enzyme production by Aspergillus niger. Res J Agric Biol Sci 1: 325-328. 